\title{
Konungarnas akademi
}

Detta kapitel kastar mer ljus över Vetenskapsakademiens politiska ideologi och hur närheten till makten färgade den genom att undersöka presidietalens framställningar av kungligheterna, i relation till relevanta politiska omständigheter. Kapitlet är kronologiskt strukturerat och uppdelat i två avsnitt, ett om frihetstiden och ett om den gustavianska tiden.

Liksom sina föregångare använde sig 1700-talets regenter av sköna konster, litteratur och lärdom för att gestalta sina politiska målsättningar och sin furstliga auktoritet. Beskyddandet av vetenskaperna erbjöd inte bara en arena för symbolisk manifestation av den egna makten utan även ett sätt att vinna aktning. ${ }^{495}$ Vetenskapsakademien fick kunglig status genom Fredrik I:s stadfästelse av stadgarna 1741, men han fattade aldrig något tycke för sammanslutningen och saknade ett personligt förhållande till den. Akademien stod desto närmare hans efterträdare Adolf Fredrik och Gustav III, vilka till skillnad från honom tjänade som organisationens beskyddare och närvarade vid dess sammankomster. Den senare var inte heller främmande för att vid ett antal tillfällen blanda sig i Vetenskapsakademiens inre angelägenheter. ${ }^{496}$ Båda regenterna sällade sig till akademiens namnkunniga donatorer, som inbegrep prominenta politiker, ämbetsmän och näringsidkare som Carl Albrecht Rosenadler, hovintendenten Fredrik Sparre, Ostindiekompanidirektören Niclas Sahlgren samt Jonas Alströmer och hans söner Patrick och Clas. ${ }^{497}$

\section{Frihetstidens kungliga konjunkturer}

Den frihetstida kungamakten var svag och kringskuren. Perioden har förståtts i termer av ständervälde och konungen liknats vid "högste kollegiechef i rikets råd". Monarken skulle ta beslut tillsammans med 
riksråden, som svarade inför riksdagen och fungerade som dess ombud. Samtidigt förblev hans symboliska makt stark, inte minst på det ekonomiska området. ${ }^{498}$ Barrington Moore Jr. har identifierat tre uppgifter och skyldigheter som vanligen ålegat härskare: beskydd, i synnerhet från utländska fiender; upprätthållande av inre lugn och ordning; samt vårdande om undersåtarnas materiella välfärd. ${ }^{499}$ Under frihetstiden stod det tredje uppdraget i centrum för Vetenskapsakademien, medan det andra i stånds-och partistridernas kölvatten blev framträdande under den gustavianska tiden.

Akademiledamöterna karakteriserade Fredrik I som en stor, vis, kärleksfull, mild, omsorgsfull och arbetsam konung som bemödade sig om att förkovra sitt rike och vars strålglans upplivade hela Sverige. Hans lovvärda och välsignade regering inbegrep en rad hälsosamma steg för att förbättra landet; slöjderna, konsterna och handeln tillväxte avsevärt och vetenskaperna utan motstycke, exempelvis genom införandet av ekonomiämnet vid universiteten. ${ }^{500}$ Carl Fredrik Piper vigde i april 1751 sitt tal till det nyss avlidna majestätet, "den mildaste Konung i verlden, under hvars Spira vår Frihet fått fästa sina rötter, och Landsens Lag börja et nytt Tide-hvarf”. Åtskilligt hade blivit bättre under hans styre, däribland lantbruket, handeln, bergsbruket, handslöjderna, vetenskaperna, uppfostringsväsendet och folkets krafter och dygder. Fredriks gemål Ulrika Eleonora var nästan osynlig i presidietalen. Den ende ledamot som uppehöll sig vid henne var Carl Wilhelm Cederhielm, som omnämnde drottningen tillsammans med hennes make och tillskrev dem delvis samma egenskaper - kärleksfullhet, omtänksamhet och idoghet. ${ }^{501}$

Flera medlemmar ställde vid frihetstidens konfliktfyllda slut Fredrik I i en fördelaktig dager. Samuel Sandels beskrev honom som upplyst och nådig, medan Johan Clason bland annat skyllde de finanspolitiska problemen under hans regering på Karl XII. Eric von Stockenström förklarade att Fredrik varit lika mycket en kännare av bergverken som framstående i kungliga egenskaper och att han kraftfullt bistått sekreta utskottets arbete med att upphjälpa järnhandeln. Stockenström hade själv beretts audiens hos honom och mindes väl det intryck en sådan vis och mild konungs vilja gjort på lojala undersåtar. ${ }^{502}$ Givet den tidsliga 
ramen kan Clason tänkas ha varit ute efter att friskriva hattarna från ansvar för rikets ekonomiska svårigheter och Stockenström efter att försvara deras handelspolitik.

Kronprinsparet Adolf Fredrik och Lovisa Ulrika uppmärksammades desto mer av Vetenskapsakademiens ordförande, vilka tog fasta på deras insatser för rikets förbättring och välfärd. Stockenström konstaterade i samband med bergshanteringens uppsving under Fredrik I att man hade "en stor förebådelse af vår dyra Arf-Furstes, Prints ADOLPH FRIDRICHS, samt des Gemåls, vår Hudaste [sic] Arffurstinnas, Princessan LOVISA ULRICAS stora och oförlikneliga samt öfver alt Svea Land vördade och älskade Dygd och Fursteliga egenskaper, om en tilkommande Regering, som skal göra oss sälla i denna och alla andra handteringar”. Ett liknande framtidsscenario formulerades av Samuel Schultze, som också presenterade Adolf Fredriks lantbruk på Ekholmsund som ett förträffligt föredöme för undersåtarna. Schultzes tillförsikt till kronprinsens lyskraft delades av Carl Gustaf Löwenhielm, som meddelade att gemene man skulle få fler förebilder och jordbruket befrämjas om bara de adelsmän som ännu inte förändrat sina gods till det bättre följde Adolf Fredriks exempel. ${ }^{503}$

Parets ansträngningar för lärdomen var ett annat tema i akademien. Olof af Acrel tog upp både den nytta vetenskaperna hade av Adolf Fredriks beskydd och Lovisa Ulrikas intellektuella engagemang, vilket behandlades av ett antal ledamöter. Acrel framställde henne som "Rikets ömmaste Klenod" och som avhållen av folket, och menade att hennes "vett-älskande dygder" skulle utgöra det mest utomordentliga riktmärke för landets barn. Löwenhielm frågade retoriskt vem som inte ville eller borde vilja lära känna naturen när den makalösa kronprinsessan vårdade sig om vetenskapen. ${ }^{504}$

Adolf Fredrik och Lovisa Ulrika figurerade för första gången som kungapar i Pipers tal om den hädangångne Fredrik I, där deras långvariga kärlek till undersåtarna berördes medan Piper enligt egen utsago förteg många övriga förebud om en lycklig regering. Den nye konungens goda egenskaper varslade om att det som inletts under Fredrik skulle fullföljas och bära frukt under Adolf Fredrik, vilken redan som kronprins varit som en far för undersåtarna. ${ }^{505}$ Andra presides kom att fortsätta på det 
paternalistiska spåret, bland annat genom att beteckna Adolf Fredrik som en far för landet och konsterna. ${ }^{506}$

Konungen Adolf Fredrik tillmättes storhet, mildhet, rättrådighet, vishet och föredömlighet, liksom en ömhjärtad, entusiasmerande och lyckosam omsorg om näringarna, Sveriges upphjälpande och den allmänna välmågan. Kungaparet ingav hopp för hushållningen, och deras omtanke och uppmuntran utlovade framsteg; inte minst skulle landet räddas från tyranni och utländskt tvång. De hade gjort en ingående inspektion av de svenska bergverken och finansierat Drottningholms fabriksanstalter med egna medel, eftersom Adolf Fredrik som beskyddare av en akademi hängiven nyttiga slöjder - alltså Vetenskapsakademien - ville framhäva dessa genom sitt och sin hustrus exempel. ${ }^{507}$

Förutom att spinna vidare på nyttotemat fortfor presidietalen även att diskutera Adolf Fredriks och Lovisa Ulrikas intresse för det konstnärliga, litterära och vetenskapliga. Konungen skildrades som de fria konsternas far och sades hysa kärlek till såväl dem som vetenskaperna och slöjderna, rikets sanna prydnader. Han sökte försköna Sverige, stimulera landets konstnärer och berika undersåtarna, och genom att uppliva vetenskaperna framkallade han en lycka som alltid åtföljde stora regenter. Ledamöterna inlät sig på Lovisa Ulrikas samlingar, kärlek till bergsvetenskapen och verksamma roll som förebild inom naturkunnigheten. Drottningens benägna stöd till de fria konsterna definierade det innevarande tidevarvet och skulle göra hennes namn vördat av en upplyst eftervärld. Två år efter Vitterhetsakademiens instiftande 1753 tillkännagav Carl Fredrik Scheffer att vitterhetens utsikter förbättrats markant sedan Lovisa Ulrika tagit den under sitt beskydd och att detta skulle bidra till dess snara uppgång. ${ }^{508}$

Adolf Fredriks och Lovisa Ulrikas son Gustav, Sveriges kronprins och den blivande Gustav III, uppträdde för första gången i ett presidietal 1747, där han fick epitetet "Rikets hopp ock ögnasten". Senare tal framställde prins Gustav som den återupplivade Vasastammens rot, rikets kära "Lifs-planta" och "Nordstjerna", en dyrbar telning och en älskad prins. Den unge tronföljaren bar löfte om storhet och skänkte hopp, glädje och styrka. ${ }^{509}$

Frihetstidens kringskurna kungamakt var ett sällsynt motiv i talen 


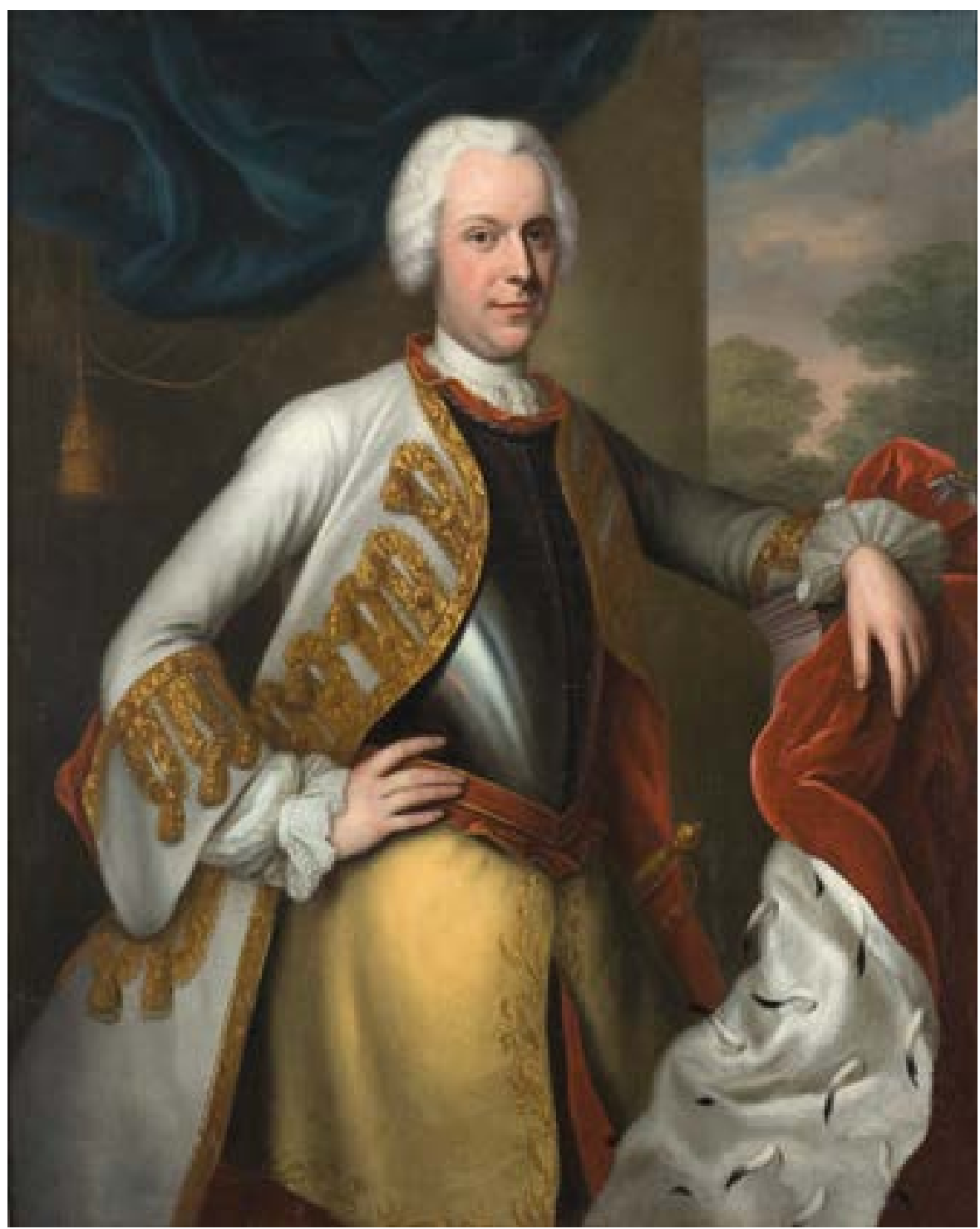

Bild 9. Balthasar Denner, Konung Adolf Fredrik. Foto: Nationalmuseum. 
under Fredrik I:s regering och kommenterades enbart av Henrik Jakob Wrede, som anförde att konungen rådde med folkets goda minne och att det var hans plikt att befordra dess väl. ${ }^{510}$ På 1750 -talet tilltog dock hänvisningarna till frihetstidens konstitutionella monarki, vilket bör ses mot bakgrund av att friktionen mellan kungaparet och hattregimen växte efter Adolf Fredriks trontillträde 1751. Denna utveckling sammanföll med att relationen mellan akademien och kungahuset försvagades för att slutligen avstanna. Motsättningen fick utlopp först på riksdagen 1755-56, där rådet och ständerna drabbade samman med Adolf Fredrik och Lovisa Ulrika om huruvida regenten hade rätten att godkänna rådets beslut, sedan i ett misslyckat rojalistiskt statskuppsförsök 1756. I skuggan av den eskalerande spänningen hävdade Erik Salander att kungligt envälde var oförmånligt för slöjderna, som den karolinska tidens varnande exempel visade. Hattarnas kanslipresident Anders Johan von Höpken gjorde gällande att såväl riksdagen som Gud satt Adolf Fredrik att styra. Han anmärkte att de som var framgångsrika vid hoven ofta blev det på grund av slumpen och ställde detta mot situationen $\mathrm{i}$ frihetstidens Sverige, där förtjänst och sanning omgav tronen tack vare konungens band till akademien. Vetenskaperna hade fått monarken att inse nyttan av sanning och kunskap respektive onyttan av falskhet och smicker, samt att en regent blev stor genom folkets seder och snille. ${ }^{511}$ Budskapet var klart nog: konungens makt och storhet kom från folket, låt vara att Gud fortfarande fanns med i bilden - åtminstone på det retoriska planet.

Ett par månader före kuppförsöket, som Lovisa Ulrika till skillnad från Adolf Fredrik hade viss kännedom om, uppmärksammade Carl Fredrik Mennander rikets "välsignade Frihets-regering". Hans presidietal slutade med iakttagelsen att Sveriges bokhandel snart skulle överskugga utlandets om denna bara kunde uppamma fler skrifter som den Vetenskapsakademien mottagit från ständerna och sedermera offentliggjort, "nämligen fullkomlig samling af de Bref, hvarmed en Svänsk Mentor leder vår dyra Cron-Prints steg från steg up til den rätta Konunga högden. Men en enda Bok, så hederlig [hedervärd] för vårt Språk, land och Folk, så nyttig för hela människo-slägtet, står ej at förmodas i hvar manna-ålder [generation]. Den delen, som af detta oskatbara arbetet 
tilförene utkommit, äger redan allmän högaktning, och är en klenod i alla Bibliotheker i Europa". Den svenske mentorn var hattpolitikern Carl Gustaf Tessin, kronprinsens lärare, som hamnat på kollisionskurs med kungaparet ifråga om Gustavs uppfostran. Riksdagens sekreta utskott lät 1756 akademien publicera Tessins korrespondens med tronföljaren som ett led i hans dispyt med Adolf Fredrik och Lovisa Ulrika. Mennanders hyllning av breven kan tolkas som en politisk handling och ett ställningstagande mot regenterna, även om han positionerade Adolf Fredrik nära Vetenskapsakademien genom att lyfta fram konungens funktion som dess beskyddare..$^{512}$

Efter att de rojalistiska stämplingarna uppdagats sommaren 1756, med utmätta dödsstraff mot flera av de inblandade och tillrättavisning av kungaparet som följd, dröjde det ett år innan konungen och drottningen förekom i något presidietal. Den talande tystnaden bröts av Carl Fredrik Adelcrantz i ett långtgående smicker av Adolf Fredrik och Lovisa Ulrika, samtidigt som han av allt att döma markerade mot dem genom att åberopa riksråden samt fältherren Agrippa och den franske ministern Jean Baptiste Colbert, vilka båda betonades på bekostnad av sina härskare Augustus och Ludvig XIV. Adelcrantz föreställde de två som stora och samhällsdrivande, och implicerade att de varit oundgängliga för sina herrar: "Där en AUGUST[US] och LUDVIG regera, felas sällan en AGRIPPA och en COLBERT til rådgivare." Johan Fredrik Kryger tycks ha agerat apologet för den frihetstida ordningen när han 1758, samma år som nya rojalistiska kupplaner avslöjades, hävdade att de svenska regeringslagarna besatt "alla de förmoner, som fordras til fria Samhällens trefnad, men i sig sjelfva ej sådana fel, som ofta sätta andra [samhällen] i förvirring och vilrådighet, emedan de [regeringslagarna] äro stridande emot sjelfva frihetens natur och ändamål". ${ }^{13}$

Ledamöternas referenser till kungahuset var därefter sparsamma, opersonliga och neutrala under några år. Adolf Fredrik gick under epitet som konungen och Kongl. Maj:t, medan presidietalen nämnde kronprinsens bibliotek och att höga överheten av iver för det allmänna bästa sökte befrämja schäferierna. ${ }^{514}$ Det korthuggna och distanserade förhållningssättet upphörde 1762, när konstruktören Carl Knutberg framhöll kungaparets föredömliga naturaliesamlande och kallade konungen 
Vetenskapsakademiens skyddsherre och nyttiga vetenskapers välgörare. Ett knappt halvår senare kungjorde instrumentmakaren Carl Lehnberg att han tillverkat ett teleskop som haft lyckan att hamna i kronprinsens ägo. ${ }^{515}$ Dessa utsagor kan betraktas i ljuset av att hattarna vid årsskiftet 1761-62 närmat sig kungahuset och bett Lovisa Ulrika förhandla fram ett slut på det pommerska kriget (1757-62), som fördes mot hennes bror Fredrik II av Preussen. Drottningens medling resulterade i en fred utan landavträdelser och ökade hovets prestige. ${ }^{516}$

Monarkerna gestaltades under en tid i samma anda som före 1750-talets slitningar. Peter Jonas Bergius trodde att hans tal om Loka källa skulle uppskattas av åhörarna med tanke på den hälsosamma inverkan kurorten haft på "hela Rikets Ögnasten" konungen. Akademimedlemmarna kunde inte med lätthet glömma den oro de känt över sin käraste landsfaders krasslighet eller den varma glädje de erfarit när han välsignats med full återhämtning. Pehr Wilhelm Wargentin redogjorde för Vetenskapsakademiens stolthet över Bengt Ferrners utnämning till lärare för Sveriges glädjeämne och hopp Gustav, en nåd som var angenäm för samtliga ledamöter. Ferrner skulle nu "få stadga den höga ynnest för Lärdom och Vetenskaper, som hos Hans Kongl. Höghet med Blodet är inplantad, som redan visat sig uti så många lysande prof, samt förvissar Fäderneslandet i gemen, men Vitterhet och Vetenskaper i synnerhet, om en blomstrande och lycklig framtid". Abraham Bäck förknippade höga överheten med ansatser att förbättra allmogens belägenhet och noterade att drottningen bistått en sjukdomsutsatt trakt genom dränering av ett träsk. Utsagor om den romerska republiken som en förebild i olika hänseenden kan dock ha rymt ekon av de tidigare motsättningarna. ${ }^{517}$

Under mössornas styre 1765-69 tonades kungahuset återigen ned i presidietalen, om än mindre dramatiskt än tidigare. Detta kan sättas i relation till att Adolf Fredrik och Lovisa Ulrika från 1765 var bundsförvanter till hattpartiet. ${ }^{518}$ Ordförandena nöjde sig förutom i ett par sammanhang med neutrala hänvisningar till konungen, Kongl. Maj:t och Adolf Fredriks regeringstid. Läkaren Zacharias Johan Strandberg slog fast att alla invånare för evigt kom ihåg Lokas nytta för Sveriges monark, medan Wargentins svar diskuterade den kungliga nåden $\mathrm{i}$ samband med Vetenskapsakademien. ${ }^{519}$ 
En förmaning till det hattlierade kungaparet går att läsa in i mösskanslipresidenten Löwenhielms Tal om ungdomens upfostran $i$ et välbestäldt Regemente (1767). Löwenhielm berömde Minos av Kreta och dennes lagar, vilka vördades av fria folk och föreskrev att

Konungen råder öfver Folket, men Lagarna öfver Konungen: At Konungen hafver full frihet at göra det goda; men har bundna händer, så snart han företager något ondt: At Lagarne lämna honom Folket i händer, såsom den dyraste skatt, med vilkor, at han skall vara dess Fader: At Gudarne ej upsatt honom til Konung för sin egen skull, utan för at vara Folkets Man: At en Konung är ovärdig Thronen, så snart han glömmer, det [att] hans skyldighet är, at upoffra sig sjelf, all sin tid och hela sin omsorg för det allmänna bästa och sitt Folk, som han är skyldig sin ömaste kärlek.

Minos upprätthållande av dessa grundsatser sades ha gjort hans rike dygdigt, lyckligt och mäktigt och honom själv gudomlig. Perserkonungarnas egenmäktighet, arrogans och krav på underkastelse hade däremot fått deras välde att duka under. ${ }^{520}$ De historiska exemplen tjänade antagligen som en inlindad varning till Adolf Fredrik och Lovisa Ulrika att inte försöka sig på något omstörtande i det sena 1760-talets antagonistiska atmosfär.

Hattpolitikern Stockenström var den ende ledamot som hemföll åt ett utpräglat hovsmicker under mösspartiets maktinnehav, när han angav att den nya regimens bevarande av Jernkontoret inte endast upphöjde Fredrik I utan också förstärkte

den glants, hvarmed vår nu varande Allernådigste Konungs och Drottnings hulda Regerings-tid [...] är omgifven, såsom lysande af Mildhet, Vitterhet och Vetenskapers samt Slögders förkofring; och et hägn, som i framtiden gifver vår nu Nådigste Arf-Furste och Dyra Kron-Prints [Gustav] tilfälle, at til detta Rikets sällhet utöfva de store och sällsynte Snilles-gåfvor, hvarmed Gud och Naturen Honom mildeligen och ymnigt utrustat. ${ }^{521}$

Efter hattarnas återerövrande av makten 1769 ökade kungahusets närvaro ännu en gång i presidietalen. Clason skildrade de prövningar som Adolf 
Fredrik fått utstå, inte minst de ekonomiska bekymren efter pommerska kriget, och höll före att hans nedläggande av spiran varit avgörande för rikets överlevnad. Clason alluderade här på Adolf Fredriks samverkan med de hattdominerade kollegierna vid deras arbetsnedläggning, som framtvingat den riksdag där hattarna återtagit makten. John Jennings prisade konungen med anledning av att Vetenskapsakademien tillåtits använda en av hans byggnader, men påpekade även att sekreta utskottet - som han själv händelsevis tillhört - varit betydelsefullt för utverkandet av denna favör. Jennings betecknade Adolf Fredrik som vetenskapernas och akademiens skyddsherre och påvisade regentens gunst gentemot organisationen. Han uppehöll sig därtill vid Lovisa Ulrikas dygd, nåd och enastående hedersbetygelse till Olof von Dalin och Samuel Klingenstierna, vilka hon förärat ett gemensamt gravmonument och i egen hög person strött jord över. Wargentins svar till Jennings tog också upp Adolf Fredriks upplåtande av lokaler och kungaparets kärlek till vetenskaperna, under det att sekreteraren registrerade ständernas välvilliga inställning till Vetenskapsakademien och att Jennings som medlem av sekreta utskottet bidragit till att sammanslutningen gynnats. ${ }^{522}$

De postuma omdömena om Adolf Fredrik fortsatte på det inslagna spåret. Arkitekten och överintendenten Carl Johan Cronstedt framställde några månader efter konungens död i februari 1771 honom som en patriotisk och omtyckt landsfader, vetenskapsälskare och svensk motsvarighet till den romerske kejsaren Titus, vars frånfälle bedrövade hela landet och uppfyllde akademimedlemmarnas tankar. Kärleken till och vördnaden för den framlidne monarken härrörde från hans rättvisa och milda styre liksom från de fredliga dygder som kännetecknat hans regering mer än någon annans; ingen furste hade varit ömmare om undersåtarnas välmåga och lagarnas helgd, eller lyckligare över riksförbättrande ansatser. Sandels deklarerade att Adolf Fredrik högaktats för sin människokärlek och sitt befrämjande av slöjder och vetenskaper. Konungen hade värdesatt dem och fria konster så till den grad att han "ville hafva det under arfs-rätt i sitt Hof besegladt: och med den kärlek Han således i sin Kongl. Famille fortplantade för desse Landets rätta prydnader, befästade Han vårt hopp och vår glädje både för den närvarande [tiden] och framtiden”. Ett flertal lovvärda och allmännyt- 
tiga inrättningar hade grundats under hans spira och uppmuntrats av riksdagen, vilken Sandels betraktade som drivande i välståndsarbetet efter stora nordiska kriget. Han uppgav därutöver att akademien på ständernas uppdrag publicerat Tessins brev till kronprinsen Gustav, som uppskattat dem. ${ }^{523}$ Huruvida dessa yttranden skall förstås som markeringar mot kungamakten är oklart, men det kan inte uteslutas att en sådan intention förelåg.

Den nyblivne konungen Gustav III gjordes till föremål för en hel del lovprisande, vilket kan kopplas dels till de stora förhoppningar som ställdes till honom under de rådande krisstämningarna, dels till en rojalism som låg $\mathrm{i}$ tiden och hade vunnit insteg bland hattpartiets anhängare. ${ }^{524}$ Gustav omgavs inte minst av religiös retorik. Cronstedt förkunnade att Försynen välsignat Sveriges kungahus och korat en tronföljare i besittning av de egenskaper som med Herrens bifall lovade fäderneslandet en lång och säll regering. Wargentins svar porträtterade Adolf Fredrik som en kärleksfull och djupt sörjd landsfader, och Gustav som en Försynens gåva som skulle göra riket lyckligt och få vetenskaper och konster att blomstra. Svaret avslutades med en önskan dels om konungens snara återkomst från Frankrike där han befann sig på resa vid faderns frånfälle, dels om att Gud skulle hålla sin hand över hans styre. ${ }^{525}$

Den nye fursten attribuerades kvaliteter som Vetenskapsakademien skulle komma att tillmäta honom under hela hans regeringstid - nåd, mildhet, kärleksfullhet, vishet, upplysning och engagemang för lärdom och nytta. Gustav ansågs vara en synnerligen upplyst domare som på ett lyckobringande och sällsynt begåvat sätt tog sig an de vetenskaper han understött redan som kronprins. Den nåd konungen lät vederfaras akademien varslade om dess fortgående kungliga beskydd och de goda konsekvenser hans visa styre skulle få för vetenskaperna och fäderneslandet. Tronen lyste mer än förut av kärlek till såväl vetenskaperna som de fria konsterna och hushållningen; Gustav återupplivade minnet av de stora Vasarnas omsorg om näringarna, varför hans namn skulle förevigas även genom ekonomin. ${ }^{526}$ Konungens kärlek riktade sig lika mycket till folket. Det hette att Gustav fattade ett helhetsgrepp om undersåtarnas lycka och månade om framför allt deras materiella välfärd, medan dessa i gengäld hyste en genuin och underdånig vördnad för sin monark. ${ }^{527}$ 
Panegyriken kunde vara nog så långtgående. Veckor före statsvälvningen hyllade Anders Schönberg Gustav III som "den bästa Konung, människo-slägtets Glädje, Thronens prydnad, främmande Folkslags förundran, och sitt folks ypperste Välgörare”, vars exempel skulle väcka patriotisk iver i alla hjärtan. Carl Rudenschöld menade att svenska språket aldrig haft större möjlighet till en guldålder, givet att Gud begåvat riket med en infödd regent som älskade och ärade modersmålet. Han hoppades att Gustav under många år skulle utgöra ett språkligt föredöme för undersåtarna och en förebild för andra regenter ifråga om furstliga karaktärsdrag. Rudenschöld fann vidare att den medeltida furstespegeln Konunga- och höfdingastyrelsen på flera punkter förtjänade att vara ett mönster för samtiden. Detta kan utifrån hans hovsmicker och nämnda furstespegels förespråkande av arvkungadöme som metod för att undvika söndring läsas som en kritik av den sena frihetstidens tvedräkt. ${ }^{528}$

Rudenschölds besvikelse över partiandan, ett "ohyggeligt ämne", var tydlig. Han hyste åsikten att språket hade gått från att vara ett gudasänt sammanhållande band till att ogenerat missbrukas för att förstöra samhället. En författning tänkt att bringa upplysning och sunda begrepp - av allt att döma 1766 års tryckfrihetsförordning - blev "på ett, för alt dygdigt folk, bedröfligt sätt, förvänd till att utgjuta bitterhet och hämd", en skamfläck för Rudenschölds "så kallade, uplysta Tidehvarf" som i görligaste mån borde döljas för eftervärlden..$^{29}$

Läkaren Nils Rosén von Rosenstein deklarerade några månader före statsvälvningen att Gustav var Guds gåva till riket och att den lärda världen länge sett honom som värdig tronen. Rosenstein bad att Gud skulle bevara konungen och hans värv, som syftade till nuets och framtidens bästa i form av egennyttans och avundsjukans fördrivande, oskuldens värnande och den riktiga frihetens säkrande - en frihet "förenad med vördnad för Konung, och inbördes förtroende Medborgare imellan". 530 Avogheten mot misshälligheter torde ha haft bäring på den sena frihetstidens förhållanden. Rosensteins resonemang om frihet förebådade akademiens politiska språkbruk efter statsvälvningen, där den rätta, gustavianska friheten kontrasterades mot ständerväldets falska dito.

Även andra ledamöter adresserade splittringen och dess olycksaliga effekter. Det konstaterades att den beklagansvärda oenigheten var 
en orsak till Sveriges svåra tillstånd, att motsättningen på riksdagen 1738-39 försvagat ständernas ansträngningar samt att det innevarande tidevarvet utmärktes av tvedräkt, egennytta och likgiltighet inför samhällets bestånd. ${ }^{531}$

En starkare kungamakt låg i luften, men den frihetstida friheten fortfor likväl att omfamnas i Vetenskapsakademiens presidietal där förflutna autokratier klandrades och därmed troligen fick tjäna som projektionsytor för antirojalistiska ståndpunkter. Clason tillkännagav att handeln under stora nordiska kriget lämnats åt sig själv och att Ulrika Eleonoras trontillträde inneburit att envälde förbytts i frihet genom en glädjefull "förlossning", som dövat smärtan från de ekonomiska problemen och haft en gynnsam inverkan på siden- och yllefabrikerna. Sandels liknade samma krig vid en ofantlig storm, efter vilken såväl freden som friheten återställts. Sten af Rabbe kan med tanke på det gängse historiebruket antas ha kommenterat samtiden när han jämförde de antika envåldsmakterna Thessalien och Epirus med övriga grekiska riken, vilka var fria småstater som tillsammans bildade en sorts republik. De förra låg efter trojanska kriget mestadels i mörker, de senare utgjorde det "rätta gamla Graekeland, som i Politiska- och Vitterhets-Historien har ett så lysande äreställe". ${ }^{532}$

Historikern Olof Celsius den yngre gav i frihetstidens elfte timme röst åt sin uppskattning av den fria regeringen, som bedömdes ha ett fördelaktigt inflytande på den intellektuella verksamheten, bland annat vältaligheten. ${ }^{533}$ Efter statsvälvningen kom akademimedlemmarna dock ganska omgående att företräda ett radikalt annorlunda synsätt, som utforskas i det följande.

\section{Den tredje Gustavens dagar}

Vetenskapsakademiens relation till regenten blev av förklarliga skäl mycket mer central efter den oblodiga statskuppen i augusti 1772, som satte stopp för de sociala stridigheterna och välkomnades av desillusionerade hattar som Höpken, Carl von Linné, Carl Fredrik Scheffer och Wargentin. ${ }^{534}$ De kungliga akademierna kom att gå regimens ärenden och utgöra "institutioner inom det kungliga nåde- och äre- 
förläningssystemet" med "viktiga ämbetsverksliknande uppgifter". Akademiernas pristävlingar och utmärkelser svarade mot regeringens ideal, invalen hade kunglig sanktion och ledamöterna arbetade officiellt för monarken. Svenska Akademien fungerade som ett informellt kollegium, Vitterhetsakademien som ett rojalistiskt organ och som en kontrollinstans för inhemska medaljer. Vetenskapsakademien förblev en kugge i statsmaskineriet, inte minst genom att makthavarna liksom tidigare gav den utredningsuppdrag. En kontinuitet med frihetstiden kan skönjas även i Gustav III:s syn på akademien som främst en nyttig och patriotisk inrättning. ${ }^{535}$

Den gode fursten förväntades under tidigmodern tid ikläda sig rollen av landsfader och vara ett dygdemönster i besittning av rättvisa, klokhet, fromhet, mildhet och nåd. Som det föreliggande avsnittet skall visa knöts Gustav III liksom sina företrädare till detta motivkomplex i Vetenskapsakademiens presidietal, vilkas upphovsmän i likhet med andra iakttagare också framställde monarken som upplyst, hjältemodig, patriotisk, välgörande och älskad av undersåtarna. Ledamöterna anslöt sig till den rojalistiska propagandans bild av konungen som en befriare och frälsare från oordning, vars styre präglades av samförstånd, trygghet och äkta frihet, till skillnad från frihetstida söndring, självsvåld och adelsdespotism. Regimens gestaltande av Gustav som en återupprättare av det förhållande mellan folk och monark som rått före det karolinska enväldets införande 1680 var däremot inte påtagbar i talen. "Frihet" gick från att avse ständernas oberoende av kungamakten till att handla om rikets självbestämmande och frånvaron av aristokratiskt förtryck genom ett styrelseskick som förbands med Gustav Vasa och särskilt Gustav II Adolf. Efter fem decennier av frihetsretorik var det lika omöjligt att ignorera den positivt laddade termen "frihet" som det offentliga samtal frihetstiden givit upphov till. ${ }^{536}$

Carl Fredrik Scheffers Tal, om förbindelsen, imellan grund-lagarnas art och folkets sällhet, som efter dem styras skal i oktober 1772 var det första presidietal som hölls efter Gustav III:s maktövertagande. Scheffer, en av konungens nära förtrogna, rörde sig med teman - frihetstidens fördärvlighet, Gustavs hjältemod, värdet av säkerhet och frihet - som kännetecknade såväl presidietalen som regimens propaganda 


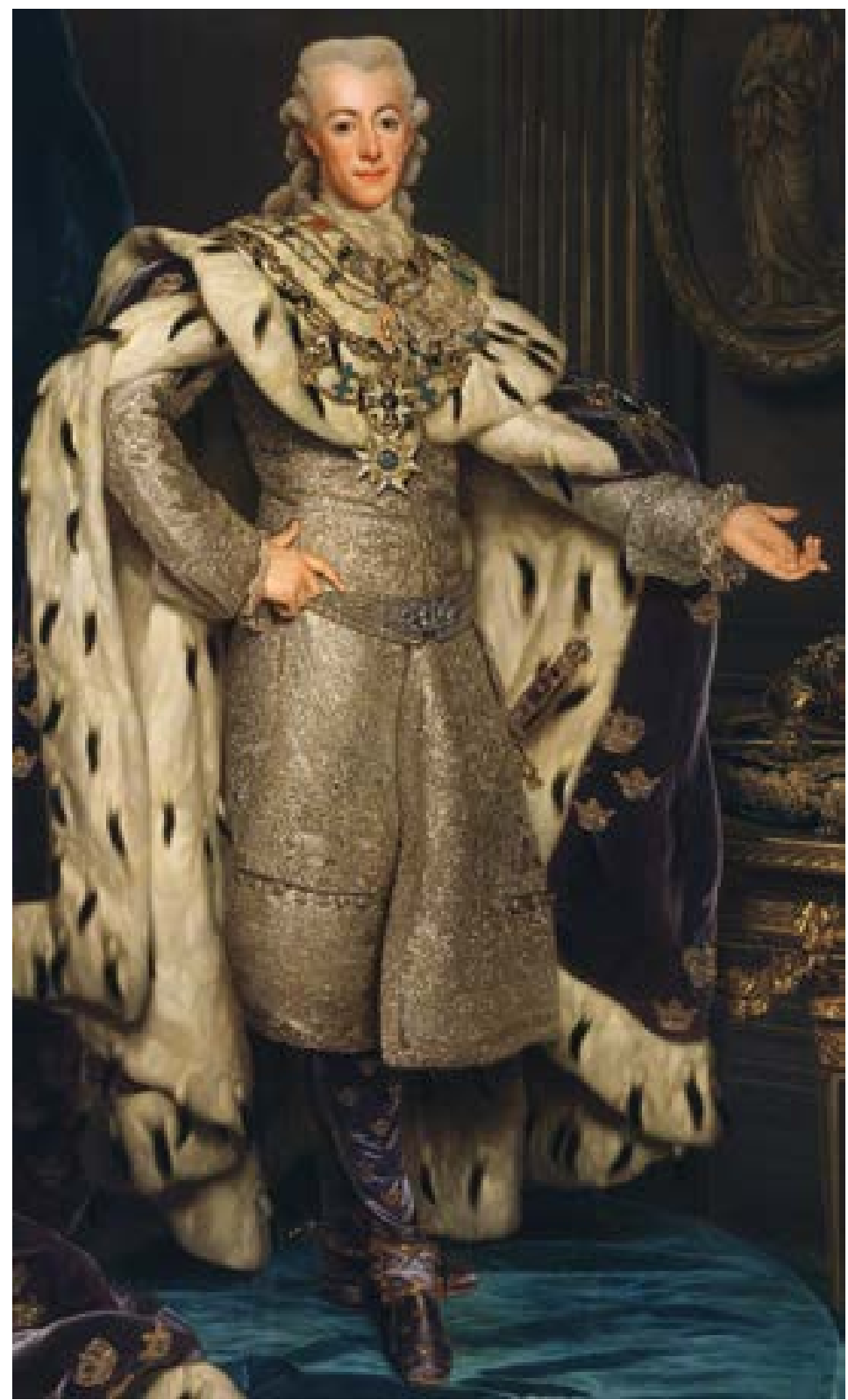

Bild 10. Alexander Roslin, Gustav III, 1746-1792, konung av Sverige. Foto: Nationalmuseum. 
och självbild under den gustavianska eran. Han fastslog att vetenskapen hade till uppgift att sätta ovanliga och stora händelser i rätt perspektiv. Ingen sådan händelse var mer betydelsefull eller förundransvärd än den gudagivna statsvälvningen, ty ett "helt Folk, som ryckes ur förderf och återställes i lycksalighet, genom et enda frimodigt beslut, genom en enda Hjeltemodig Bedrift, på en enda dag och utan et enda lifs spillande, är visserligen i den Moraliska Verlden, hvad man i Naturen kallar et underverk". Om det stämde att fred, lugn, privategendomens helgd och näringarnas frihet utgjorde den högsta lycka och att lagarna, speciellt grundlagarna, var förutsättningen för denna ägde Gustav "inom sig Sjelf den största förnöjelse, som någon Regent, ja, som någon dödelig här på jorden njuta kan”. Wargentin anmärkte i sitt svar att Försynen under Scheffers presidium skänkt svenskarna mer än de vågat önska eller kunnat förvänta sig. Regeringssättet hade förändrats till det bättre, en rättfärdig frihet förstärkts, den enskilda och allmänna säkerheten återinförts. Sveriges varaktiga sällhet var inom räckhåll och framtiden hade aldrig varit ljusare för näringarna, konsterna, vetenskaperna och Vetenskapsakademien, vilken fröjdade sig över detta. ${ }^{537}$

Det gudomliga mandat Scheffer och Wargentin attribuerade Gustav III återkom hos andra ledamöter. Konungen sades vara en himmelsk gåva som likt Gustav Vasa frälste riket från fara, och om Gud ville skulle hans strävanden efter förbättring bära frukt under en välsignad och lång regering. Allt förmånligt som riket upplevde från Gustavs tronbestigning och framåt skedde med Herrens goda minne. Monarken parallelliserades på hävdvunnet, kvasireligiöst manér med solen; liksom den vederkvickte och gladde naturen, upplivade en vis furste undersåtarna i deras utsedda sysslor. Gustavs tron, som lyste inte minst i vetenskapernas krets, avgav en värme som ingöt välvilja, patriotism och strävan efter oförgänglig ära i allas hjärtan. ${ }^{538}$

Presidietalen utmålade ofta Gustav III som nådig, antingen i hänvändelser till honom eller genom direkta eller indirekta karaktärsteckningar av och referenser till regenten. ${ }^{539}$ Ibland tillskrevs denna egenskap Kongl. Maj:t, som kunde ha en bredare syftning än konungen. ${ }^{540} \mathrm{Gustav}$ framstod också som mild, god, storsint, generös, välvillig, arbetsam, effektiv, stor och mäktig. ${ }^{541}$ Carl Sparre betecknade honom som rikets 
"store Ledare", medan Carl Fredrik Scheffer hävdade att hans storhet framgick av att han med en åtgärd som skulle komma att få eftervärldens tack begränsat sin egen domsmakt. ${ }^{542}$

Andra kvaliteter som kopplades till konungen var vishet, insiktsfullhet och upplysning. ${ }^{543} \mathrm{Han}$ uppgavs vara en filosof som bekantgjorde sin omsorg om egendomsrätten på ett upplyst vis och själv skrev utkastet till grundlagen, vilket vid sidan av hans arbete med att utveckla uppfostringsväsendet vittnade om hans djupsinne. Han var den mest upplyste konung med "de största naturens förmoner" och "den visaste kunskap at dömma om alt det, som länder til sit Lands välfärd", samtidigt som han tillhörde de mest upplysta kännare av konster och vetenskaper som suttit på eller nedanför troner. ${ }^{544}$

Ett annat tema i framställningarna av Gustav III var hans moraliska reslighet. En uttryckt förhoppning om förbättrade seder efter statsvälvningen grundade sig inte bara på lagarna utan än mer på lagstiftaren, vars ändlösa kärlek till dygd och ära skulle jaga lasten på flykten. Det hette att dygden lyste i Gustavs handlingar, ärade kungavärdigheten och krävde lagens okränkbarhet. Det spåddes att Gustavs regering skulle bli en lysande tid med avseende på snillebragder, djärvhet, ädelmod, patriotism, ärlighet och måttfullhet. Mot undersökningsperiodens slut konstaterades att hans författningar faktiskt förädlat tänkande och seder. ${ }^{545}$ Gustav beskrevs i linje med dessa egenskaper som en fridsfurste. Bengt Bergius skildrade det stora nordiska krigets hemska återverkningar och menade dels att krig bidragit till att det frihetstida nyttoarbetet inte fullt ut lyckats, dels att utdragna och bistra krigstillstånd var grymma landsplågor. I vad som sannolikt utgjorde ett försök att övertyga konungen om behovet av grannsämja tillade han att Gustavs "fredälskande sinnelag och förträffliga Stats-konst" ingav hopp om att väpnad konflikt kunde undvikas. ${ }^{546}$ Alla delade dock inte denna pacifistiska inställning. Axel Magnus von Arbin framförde att han inte fruktade grannarnas fredsbrott och att det om olyckan var framme inte skulle saknas soldater fostrade av Gustav, vilka skulle låta sig inspireras av historiska svenska hjältar. ${ }^{547}$

Gustav III framträdde vidare som en nyttofurste, vars regeringssätt utmärktes av vett, idoghet och slöjd. Konungen betraktade med gil- 
lande sina trogna undersåtars ansträngningar att med flit och gagneliga näringar öka sitt välstånd, och under Gustavs spira skulle svårigheterna som behäftade handeln övervinnas och ett friare och mer omfattande varuutbyte åstadkommas. Om han fick leva lika länge som sin namne Gustav Vasa skulle hans regering få gynnsamma konsekvenser inte minst i form av en fördubblad befolkning som var oberoende av utlandet för sin försörjning. ${ }^{548}$ I ett fall, Eric Schröder, var tonläget något mindre entusiastiskt. En kunglig förordning av år 1775 om friare inrikes spannmålshandel skulle alltid ha "et hedrande rum ibland nyttige Författningar, ehuru verkan deraf ännu icke lärer hafva aldeles svarat emot afsigten". 549

En av de mer oförblommerade skildringarna av nyttofursten Gustav III återfinns hos Jean George Lillienberg, som meddelade att positiva exempel inte är verkningslösa när en vis monark stöder och uppmuntrar nyttiga anstalter. Konungen inhämtade ständigt kunskap om ämnen som gjorde riket starkare och mer välmående. Han begrep bergsnäringens värde och hade i likhet med sina stora föregångare inspekterat den, varvid undersåtarna blivit varse överhetens intresse för sådant som rörde rikets väl. Med hans inspirerande nåd kunde näringen förväntas nå än högre höjder, eftersom denna var dess främsta drivkraft. Gustav hade tydligt visat sin omtänksamhet om metallindustrin och gynnat kopparförädlingen, vilket föranlett en rekordexport av kopparsmide. Till följd av dessa satsningar hade manufakturägarna börjat tävla ordentligt med varandra och metallförädlingen fått den största tillväxt. Lillienberg talade om "de sanskyldiga tacksamhets-offer" som Sveriges bergsmän frambar till tronen och önskade att regenten "måtte i sin [livs]tid få höra Närings-idkare i allmänhet sjunga, om [...] deras sällhet, under Konung GUSTAFS Spira, och Bergen derå gifva et fördubbladt genljud". 550

Gustav III skildrades också som en vetenskapernas och de sköna konsternas furste, vilken älskade, beskyddade och uppmuntrade dem och deras idkare. Givet att riken med regenter som drev på nyttiga vetenskaper och visste deras värde var lyckliga kunde Sverige räknas som det mest sorgfria landet. Både riket och Vetenskapsakademien gladdes över Gustavs förträffliga understödjande av vetenskaperna, och akade- 
mien prisade tacksamt Försynen för att ha skänkt den en konung vars beskydd fick vetenskaperna att blomstra till evärdlig ära för hans tid. ${ }^{551}$

Slutligen beskrevs Gustav III som vördad och älskad. Folket höll honom kär och bad till Gud om att den gustavianska tronen skulle konsolideras genom en kronprins. Enligt Joachim Wilhelm Lilliestråle hade undersåtarna satt sin lit till och älskat Gustav redan som kronprins. Samme preses lade sig på en teoretisk nivå när han anförde att kärleken till monarken och fäderneslandet utgjorde villkoret för social harmoni, då denna känsla stärkte samhällsbanden och gjorde så att en anda rådde över allt. ${ }^{552}$ Konungens besvarande av folkets kärlek utgjorde ett givet motiv i talen. Gustav III var en nådig landsfader som styrde mer med kärlek än med fruktan, ömmade för sina lojala undersåtar och eftersträvade deras sällhet. Deras lycka var emellertid inte tillräcklig för honom; han ville även att de skulle känna sina förmåner, hålla av sitt fädernesland, verka för kommande generationer och förnöjda tacka Gud. ${ }^{553}$ Lilliestråle upplyste om att Gustav hyste en faderlig omtanke om sitt folk och fröjdade sig över dess lycka, och om att det var hans nöje att arbeta och tänka för undersåtarna. Konungen tillmättes härvidlag en djup människokärlek: "Den falska styrsel-konst hos honom intet gäller, Som kortsynt, svag och trång, blott thronens fördel ser: Hans föremål är stort, Hans hjerta uplyft mer: För mänsklighetens hjelp vår TITUS tårar fäller: Den har det främsta rum i GUSTAFS höga själ: Han känner ömt och qväls [lider] af hvad Hans land kan trycka: Sin Kronas höga rätt, Sin fördel och Sin lycka Han ser i folkets väl." 554

En variation på samma grundtema kom till uttryck i presidietalens iscensättningar av Gustav III som en medicinskt välgörande furste, som bekymrade sig om sjukdom, vidtog hälsofrämjande åtgärder och tillsammans med sin familj utgjorde ett lysande föredöme genom att låta ympa sig med koppor. ${ }^{555} \mathrm{En}$ annan variation återfinns i framställningarna av Gustavs filantropiska ådra. Carl Sparre redogjorde för hur det ökade tiggeriet väckt konungens medlidande, motiverat honom att i egen hög person begära ett utlåtande från Stockholms magistrat och fått honom att försöka lindra misären. Läkaren Herman Schützercrantz (Schützer) diskuterade monarkens oförfalskade engagemang för fattiga 
barnaföderskor och attribuerade honom en medfödd människokärlek och empati. ${ }^{556}$

Som brukligt var belystes Gustav III:s egenskaper med hjälp av historien. Carl Fredrik Scheffer liknade honom vid den atenske lagstiftaren Solon; båda hade upphävt lagar som kostat åtskilliga människoliv, låt vara att Gustav överträffade sin antike föregångare och att svenskarnas lycka skulle överträffa atenarnas eftersom konungens gärning skulle bli bestående. Scheffer liknade därtill Gustav vid den romerske kejsaren Trajanus, bland annat ifråga om välgörande lynne och band till folket. Även i detta sammanhang gavs den svenske fursten ett försteg framför det antika exemplet, samtidigt som Scheffer anmärkte att monarken alltid på något sätt skulle överskugga forntidens stora män, vad än för jämförelser som gjordes med dem. ${ }^{57}$

Gustav III identifierades alltifrån sin födelse som "den tredje Gustaven", efter Gustav Vasa och Gustav II Adolf. Gustav Vasa utgjorde en viktig referenspunkt i det förflutna, inte minst för den tredje Gustaven själv. ${ }^{558}$ Lilliestråle förutsåg att Gustav III "Den förste GUSTAF likt" skulle frälsa landet från olycka, ge rikskroppen livskraft och göra Sverige lyckligt. En mer subtil parallellisering går att läsa in i Arbins utsaga att krigsvetenskapen, "förädlad i en GUSTAF WASAS händer", betvingade såväl utländska tyranner som inhemska våldsutövare, varefter fred, lugn, sedesförbättring, upplysning, konster och vetenskaper infann sig. ${ }^{559}$ Alla dessa honnörsord känns igen från skildringarna av Gustav III, som Arbin torde ha avsett lika mycket som Gustav Vasa. Hänvisningarna till inrikes våldsverkare och till främmande tyranner kan ur det perspektivet förstås som anspelande på partierna respektive de danska och ryska regenterna.

Nils Adam Bielke konstaterade i sitt presidietal om hushållningen under Gustav Vasa att ämnet borde beröra åhörarna desto mer eftersom de levde i en tid då den bäste konung ärofullt och framgångsrikt väckte minnet av vad "den Förste GUSTAF" gjort för fäderneslandet. De uppmanades be för att den som besatt Gustav Vasas namn och hans ömhet för folket också skulle besitta hans livslängd. Bielke menade att ingen från Karl den stores tid intill det innevarande tidevarvet kunnat mäta sig med Gustav Vasa; "Hjeltar kunna finnas i alla åldrar; men 
där vil Secler til, at alstra GUSTAVER." Gustav III likställdes således av allt att döma med den oförliknelige reformationskonungen. Talet liknade Gustav Vasa vid Julius Caesar och porträtterade honom som en stor, vis och lärd furste med ett ädelt hjärta. Försynen hade sänt den hjältemodige monarken att rädda riket, som han lyft ur slaveri och våld samt lösgjort från de problem som orsakats av orkeslöshet, okunnighet, vrede, upproriskhet och utländsk förslagenhet. Han föreställdes därutöver som en formidabel näringsfurste med livaktigt intresse för ekonomin och fredlig välståndsökning, och som en lagförbättrare och ordningsam far för sitt folk, upplivad av kärlek till fäderneslandet och omsorg om undersåtarna. Gustav Vasas utomordentliga kvaliteter hade fått folket att älska honom innerligt, efter att det förvissats om att han oupphörligt aktade på dess bästa. ${ }^{560}$

De karaktärsdrag och gärningar Bielke tillskrev Gustav Vasa påminde starkt om dem som associerades med Gustav III i presidietalen. Det är med hänsyn till den explicita sammankopplingen av de två Gustaverna mer än sannolikt att den historiska tillbakablicken också syftade på samtida förhållanden. Utsagorna om våld, träldom och utländska illfundigheter lär ha anspelat på både frihetstiden och den katolska unionstiden, då det svenska riket hade varit invecklat med Danmark och Vatikanen.

Wargentin följde Bielke i spåren när han i sitt svar betonade att Gustav Vasa hade få uppenbara likar och att han varit en insikts- och kärleksfull landsfader, vars arbete syftat till ett mäktigare rike med en stor, välmående befolkning. Gustav Vasa knöts liksom hos Bielke tydligt till Gustav III: "Lyckligt det Land, som länge får styras af en så vis och öm Fader! Lyckligt Sverige, som åter ser en GUSTAF på Thronen, brinnande af samma hjertelag [goda sinnelag] emot sina undersåtare! Himmelen förläne Honom ock samma lycka och rätt Kongliga förnöjelse, at, efter en lång och ärefull Regering, få se sit Rike, genom allmänna hushållningens förbättring, försatt, utur största vanmagt, til högsta välstånd och anseende!"561

Den 2 maj 1792, drygt en månad efter Gustav III:s död den 29 mars samma år, höll ämbetsmannen Zacharias Zachariae Plantin ett tal som inleddes med en veklagan över den mördade konungen. Vetenskapsaka- 
demiens medlemmar sades vara vana vid att på sina möten uppleva en tillfredsställelse som kom sig av att de verkade för allmännyttan, under goda lagar och i sämja och lugn. Nu avslöjade de bedrövade ledamöternas klädedräkt och förskräckta ansikten en smärtsam förlust: "Svea Rike har förlorat Sitt Öfverhufvud, Vetenskaperne en Älskare och vår Academie sin Höga Beskyddare." ${ }^{562}$

Plantin förklarade att alla tre Gustaverna brytt sig om såväl ärorika krigsbragder som vetenskaper. Saknaden efter Gustav III var så mycket större eftersom hans kärlek till vetenskaperna anvisade hans regering en strålande plats i deras historia och honom en framskjuten position i annalerna. Ingen vetenskap hade förfördelats under den genialiske sanningsälskarens styre, då naturforskningens utmärkta beskydd väckt förundran. Till det kom att konungen ömmade för ungdomens uppfostran och på alla vis sökte sprida verklig upplysning för att undersåtarna skulle tillgodogöra sig ett fritt och lagbundet samhälles förmåner, vilket ännu inte alldeles förverkligats. Plantin diskuterade även Gustavs stora påverkan på litteraturen och den konstnärliga verksamheten. Genom språkets och smakens förkovran hade "det gamla Afguderiet för utländingars nog medelmåttiga företräden, som hittils qväft [kvävt] all egen upkomst" lyckligtvis försvunnit, "hvarföre ock Sverige nu ej behöfver Roms biträde, at i Marmorn uttrycka sin tacksamhet på GUSTAF Den III:djes Graf" ${ }^{563}$ I likhet med Gustav Vasa före honom hade Gustav III befriat riket från utländskt, enkannerligen romerskt, inflytande.

Johan Carl Wilcke hävdade i sitt svar till Plantin att den hädangångne monarkens dygder alltid vida överskridit Vetenskapsakademiens förmåga att berömma honom och att hans tal på ett värdigt sätt formulerat organisationens sorg. Akademisekreteraren betonade också ledamöternas ledsnad, men lade till att hela landet genljöd av bedrövelse. ${ }^{564}$ De postuma beskrivningarna av Gustav III reproducerade som synes flera av de teman som varit tongivande under hans regeringstid, vilken fortsatte att förbindas med enighet, frihet, sanning, dygd, nytta, upplysning och kulturens och lärdomens befordrande.

Kronprinsen Gustav Adolf, den blivande Gustav IV Adolf, relaterades från första stund till kungafamiljens lärdomsbeskydd. Anders Sparrman framförde vid hans födelse på hösten 1778 Vetenskapsakademiens för- 
hoppning att Gustav III:s efterträdare skulle bli en vetenskapsgynnare av samma rang som sin far. I detta sammanhang tecknades en idealbild av det Sverige tronföljaren skulle komma att regera över:

Himmelen upfylle våra brinnande önskningar!!! så skall den efterlängtade Prinsen, då Han en gång uplyfter Sin Spira öfver et redan lyckligt Folk, dana et Saturni Tidehvarf för Sina glada Undersåtare, hvilka, uplyste af redan gynnade och florerande Vetenskaper, skola med deras snille-foster än mer hedra och gagna Hans tid och efterkommande Secler. Då, om icke förr, skola Människo-kärlek och Patriotisme, jämte Vetenskaper och Slögder, på Svenska kölar föras och utbredas til Södra Verlds-halfvan, samt fördubblade återflyta til Europa och vår älskade Nord.

Wilcke anmälde senare i samma anda att den upplysning informatorn Nils von Rosenstein inpräntat hos rikets högt värderade kronprins, "Samtidens glädje, Framtidens hopp", skulle göra eftervärlden säll. ${ }^{565}$

Plantin riktade sig efter Gustav III:s död till Gustav IV Adolf, som bar "et älskadt Namn och med GUSTAVERS Blod ärft deras kärlek för Fosterbygden". Han frambar en önskan om att den käre Vasaättling Försynen nu korat till rikets överhuvud skulle få skörda frukten av sin innerligt saknade fars visa insatser för att skapa fria och laglydiga undersåtar. Talet smickrade också Gustav Adolfs förmyndare och farbror, hertig Karl. Plantin hoppades att de sköna anlag som till folkets glädje så tidigt visat sig hos Gustav Adolf skulle nå sin fulla potential under tillsyn från denne hjälte, som Gustav utsett till den omyndige konungens stöd. Karl skulle leda den unge härskaren till sann ära och dygd, och med Guds hjälp och svenskarnas mod bevara hans tron, "som in- och utländsk tvedrägt, i Vasarnas tid, väl förmått skaka, men ej öfverända kasta". ${ }^{566}$ Vetenskapsakademiens ledamöter anpassade sig således liksom 1772 synbarligen friktionsfritt i sina presidietal till det förändrade politiska läget genom att snabbt flytta över sina lojaliteter och vända sig till den nya regimen. Den nye regenten framställdes analogt med den gamle som en Gustavers och Vasars arvtagare, under det att inarbetade teman som undersåtlig frihet och enighet, kunglig dygd, kärleksbandet mellan furste och folk samt monarkens gudomliga mandat fortfor att åberopas. 
Frihetstiden ställdes efter statsvälvningen vanligen i en ogynnsam dager och kontrasterades därvid mot det bättre gustavianska tidevarvet. Gustav III lade beslag på värdeordet "frihet", medan den föregående perioden tillskrevs falsk frihet, motsättningar, självsvåld, godtycke, korruption, svaghet och ett förfall som fört riket till undergångens rand. ${ }^{567}$ Presidietal refererade till frihetstidens förvirring, bullersamma förändringar och försämrade inrättningar. Enligt Rosenstein den yngre hade det under denna tid förelegat en tro att friheten kunde äga bestånd "utan personlig säkerhet, med urtima Domstolar och förtryckande grundsatser" och att "alt hulpit [hjälpt], blott vissa Medborgare förlorade". ${ }^{568}$

Carl Fredrik Scheffer använde tydligtvis historien som en projektionsyta för såväl frihetstiden som det karolinska enväldet. Han menade att antikens Grekland präglats av instabilitet, förföljelse, konflikt och maktkamp, företeelser som var oförenliga med den sanna lycksaligheten. De gamla grekerna hade ömsom upphöjt, älskat och åtlytt, ömsom vanärat, förkastat och förvisat samma män, ofta bara för att de ledsnat på att höra dem berömmas. Folket förtrycktes ena stunden av det värsta envälde och hängav sig den andra åt det skamligaste själsvåld. Detta tillstånd berodde på konstlade regeringslagar som var "fulle af oenighets-frön", oförmögna att åstadkomma jämvikt och i konflikt med naturens ordning. Scheffer skyllde den romerska republikens missförhållanden på regeringslagarnas obeständighet och mångfald, medan folk och senat liknades vid två folkslag som drevs av ett konstant begär att inkräkta på varandras rättigheter. Han avskydde och äcklades av senatens orättvisa, arrogans, hårdhet och folkförakt, liksom av menighetens olydnad, ansvarslöshet, bångstyrighet och försummande av sina plikter. Kejsardömets brist på lagar var emellertid inte heller något att hurra för. Scheffer kom fram till att romarna "både under Frihets tiden och under Enväldet" varit lika olyckliga som strålande; de hade likt grekerna hemfallit åt rivalitet och osämja, alltid i frihetens namn men utan att veta vad den faktiskt innebar. ${ }^{569}$ Scheffers terminologi gör det troligt att han även avsåg det karolinska och det frihetstida Sverige. Detsamma kan sägas om attributen osämja, självsvåld och falsk frihet som ju under den gustavianska eran frekvent tillmättes frihetstiden.

Frihetstiden verkar också ha vilat tungt över Scheffers skildring av det 
barbariska feodalsamhället, där folket levde i träldom och stormännen trots sitt självsvåld och sin makt inte kände någon lycka: "De oroade hvarannan [varandra] inbördes, stridde om företrädet, täflade om alla Borgerliga förmoner, grepo til vapen vid minsta anledning til missnöje, och som Öfver-Herren var för svag, at någonsin göra sig lydd, så blef i et så inrättadt Samhälle alt öfverlämnadt til våld, och den svagare altid et rof för den mägtigare.” Välstånd, säkerhet och ordning lyste med sin frånvaro, konsterna, handeln och jordbruket var illa däran, folket utnyttjades av makthavarna ${ }^{570}$ Utsagorna om oordning, osäkerhet och interna slitningar torde ha åsyftat frihetstiden lika mycket som medeltiden. Den svage överherre som inte kunde komma till rätta med våldet och förtrycket var inte endast den generiske feodalfursten utan även Adolf Fredrik.

En indirekt polemik mot frihetstiden går vidare att urskilja i Scheffers resonemang kring olika juridiska system. En sorts länder hade lagar som fick den styrande och undersåtarna att oavlåtligt frukta varandra och formellt gjorde den förre beroende av de senare, låt vara att denne i praktiken kontrollerade dem genom deras korruption, vilken blev till "en Stats-lära" som upphöjde de mest lastbara. Lagarna gav visserligen sken av att vara till för den enskildes och det allmännas säkerhet men kunde inte förhindra beständiga oroligheter, de egenmäktigas raseri eller de sedligaste medborgarnas förorättande. I ett annat slags rike vidtog det härskande partiet under "en påstådd Frihet, [...] stundom af okunnighet, oftare af harm och bitterhet emot Gen-Partiet [...] mått och författningar til landets förödande; likt Envålds-Herren deruti, at bägge erkänna ingen Lag, utan styra efter godtycko". ${ }^{571}$ Samtida iakttagare förnam säkerligen en rad likheter mellan respektive system och det frihetstida Sverige - närmare bestämt korruption, självsvåld, tvedräkt och falsk frihet.

Scheffer riktade vid några tillfällen en mer direkt kritik mot frihetstiden. Antika och samtida europeiska lagars fel hade varit än mer kännbara i riket under det gångna halvseklet, då lagstiftningen lidit av omfattande, sedesfördärvande brister och krävt en myckenhet blod, i linje med partiandans grymhet och på grund av bitterhetens och hämndens föreskrifter. Han fann det beklagligt att frihetens verkliga 
innebörd var oklar i ett rike som så länge och träget uppehållit sig vid och idealiserat den. Denna reflektion utmynnade i en regelrätt diatrib mot frihetstiden, som Scheffer benämnde "missfostret":

jag vågar tilspörja [fråga] hela vår opartiska Allmänhet, huru ofta detta ordet [frihet] blifvit missbrukadt, huru oförsynt sjelfva saken blifvit bårtblandad med alla de Passioner, som upeldat hvar enskild Medlem af detta Samhället? Den äregiruge och storsinte Medborgaren har kallat Frihet, at få styra Riket såsom Ledare af et Parti; den penning-giruge, at få sälja sitt Tankesätt, och ofta sina dyrbaraste Rättigheter i Samhället; den late och vällustige, at få upoffra sina skyldigheter åt sina nöjen; den sjelfsvåldige, at få följa obehindrad sitt tycke, och lyda ingen mer än sig sjelf; den orolige och egennyttige, at få upblåsa tvedrägts-andan, upägga [uppegga] Partierne, och ymsom [ömsom] stå med bägge, til at säkrare vinna egen fördel $i$ alla skiften och alla hvälfningar.

Här återfinns karakteristiska inslag i den gustavianska bilden av frihetstiden, inte minst den falska friheten, vilken kan kopplas till Scheffers skepsis gentemot "fullkomliga Republiker", som av för honom okända skäl kallades "Fria Stater". ${ }^{572}$

Sven Bunge diskuterade ett tidsligt ospecificerat men klart frihetstida Sverige, där styresmännen saknade övertygelse om sin egennyttas sammanfallande med allmännyttan och framtvingade flit genom lagen, vilket satte dem i motsatsställning till människans naturliga frihetsbegär. Oenighet utgjorde ett särmärke, delvis till följd av konstitutionen, som kunde göra att makthavarna hyste sinsemellan diametralt olika åsikter, varvid ytterligheter uppstod. En bättre tid hade förvisso varit i antågande, men friheten uteblev likafullt medan tvånget kvarstod. Bunges domslut över frihetstidens hushållning var föga gynnsamt. Den strikta uppdelningen mellan stads- och landsbygdsnäringar hade varit av ondo och såväl jordbruket som bergshanteringen missvårdats, den sistnämnda så till den grad att han inte ville fördjupa sig i frågan för att slippa göra "en obehagelig målning". Okunskap om riket och de rätta ekonomiska grundsatserna hade vållat ostadighet i näringarna och spritts genom otaliga stridsskrifter, vilkas virriga uppslag och tomma 
ord som regel förvillat läsarna. De få genomtänkta texterna hade generellt sett inte beaktats. ${ }^{573}$

Bunge var inte den ende ledamot som uppmärksammade frihetstidens ekonomiska och ekonomisk-politiska olägenheter. Lillienberg noterade att Trollhättans slussar när de väl färdigställts skulle hedra perioden men hade annars inte mycket positivt att tillägga. Han ogillade de betydande satsningarna på vanskötta och avsigkomna fabriker som bearbetade utländska råämnen, om än intentionerna bakom dem varit goda. Skakningar hade spillt över från "en konstlad och ostadig rörelse-art”, alltså manufakturväsendet, till bergshanteringen, som trots stora felgrepp och omvälvningar i hushållningen och politin förblivit stabil; näringen hade inte för inte gjort mest för att kompensera de förluster riket åsamkats genom olycksaliga och kostsamma krig. Gustaf Adolf Leijonmarck uppgav att oordningar och misskötsel inom näringarna och rörelserna riskerade vara till förfång för utrikeshandeln, vilket nyliga - det vill säga frihetstida - skeenden visade. Mindre utvecklade näringar borde som regel inte premieras på bekostnad av mer utvecklade, och det var nyttigt att vinnlägga sig om flera näringar som kunde förstärka varandra. Han förklarade att riket upplevt tider med annorlunda principer och önskade att varken ett sådant ledsamt förfaringssätt eller finans- och penningväsendets tidigare problem skulle upprepas i framtiden. ${ }^{574}$

Frihetstidens undermåliga lagstiftning var ett annat ämne som berördes i de gustavianska presidietalen. Lilliestråle observerade att ständerna länge klagat över sjuka lagar, att inget botemedel stått att finna och att sjukdomen kanske förvärrats från en riksdag till en annan genom otillräckligt motiverade författningar. Carl Sparre anmärkte att den frihetstida ordningen hade respekterats någorlunda inledningsvis och frambringat författningar som skulle ha kunnat vara nyttiga, om inte deras växande antal gjort det omöjligt för ämbetsmännen att verkställa dem. Makthavarna var självsvåldiga och laglösa, och tvingades till slut vända sig till Adolf Fredrik för hjälp. Sparre alluderade sannolikt på frihetstiden när han menade att kuvandet av osämja, missbruk och förtryck resulterade i omtanke, lugn och idoghet, och att en rättfärdig politi måste ge vika för hemska skuggor om "förvänd Stats-konst" satte 
egenmäktighet över allmän och enskild säkerhet, om tvångsmedel förknippades med ett menligt ämbetsmannavälde "til Medborgares förtryck och Tyranniserande" samt om mångvälde och självsvåld uppfattades som frihetens kärna fram till dess att de bringade regeringssättet till avgrundens rand. ${ }^{575}$

En mer sammansatt syn på frihetstiden uttrycktes av Sandels, som slog fast att fred och frihet efter Karl XII:s död blivit riksdagens högsta ändamål. Båda hade gjorts till föremål för heliga löften och hanterats klokt och värdigt, samtidigt som kunglig myndighet och rätt aktats. Han påpekade dock att detta gällde enbart Ulrika Eleonoras och i viss mån Fredrik I:s regering, eller "Regeringssättet, såsom nytt", när ständerna trots den politiska splittringen ivrade för att bistå sin överhet och läka rikets djupa sår. ${ }^{576}$

Sandels redogörelse för den tidiga frihetstidens ekonomiska politik var övervägande neutral eller positiv. Det hette till exempel att regeringen gynnat manufakturer och hantverk, och att Sverige upphjälpts och kommit att åtnjuta ett handelsöverskott. Sandels uppvisade en tydligt apologetisk attityd till hattpartiet då han hävdade att 1738-39 års riksdag lagt en rejälare grund för slöjdernas och manufakturernas tillväxt. Deras privilegier och importförbuden gav effekt, och en "allmän täflan [...] för slöjde-näringar och Manufactur-inrättningar" infann sig som inte ens förberedelserna inför hattarnas ryska krig stäckte. Riksdagen befrämjade särskilt textilfabrikerna, varav flera nådde framgång - inte minst klädtillverkningen, som framgångsrikt hämmade importen av utländska plagg. Många förtjänstfulla fabriksanstalter tillkom och deras korta livslängd berodde inte på avsaknaden av nödvändig uppmuntran, utan på att stödet missbrukades. Frihetstiden tillerkändes även andra ekonomiska landvinningar, som att lantbruket förbättrats avsevärt och att nya växter introducerats. Allt hade likväl inte varit frid och fröjd. Ingen kunde "göra sig annat begrep om Rikets tilstånd, om näringar, om handel, än såsom altid vaklande". Merparten av den vinst hushållningen borde ha genererat hade försvunnit, och Sveriges penningproblem hade kvävt de fina inrättningar som gynnats på senare tid. De monetära bekymren, tilltagande lyx och import av umbärliga 
varor gjorde att landet inte kunde konkurrera ifråga om produktion, export och sjöfart. ${ }^{57}$

Sandels levererade också kritiska synpunkter på det närmast förflutnas politik. Han angav att "den så kallade frihets tiden" dragits med olika ekonomiska rättesnören och motstridiga tänkesätt, vilka ledde till förföljelser. De författningar som stadgades vid de sista frihetstida riksdagarna överlevde sällan längre än en mandatperiod, och partimotsättningarna betvingade själva förnuftet: "Besynnerligast var, at alle kände oredan i penning-verket, och dess tryckande följder; men icke ens medborgare i Samhället af uplyst förstånd och god vilja kunde under flere Riks-möten förena sig om hjelpmedlen." Sandels ifrågasatte vidare hattarnas krig och ekonomiska politik. Näringarna må ha fått omfattande uppmuntran, men de ansenliga hinder som de mötte skulle ha avgått med segern om det inte varit för statsvälvningen. Manufakturväsendet var snedvridet, eftersom den med rätt kontakter kunde sko sig på det allmänna genom belöningar eller lån som sedermera avskrevs. Pengarna gick ofta till lyxkonsumtion och emellanåt till alldeles för stora lokaler. ${ }^{578}$

Några presidietal gav frihetstiden merendels goda vitsord. Bengt Bergius meddelade 1780 i en sammanfattning av de fyrtio år som gått sedan Vetenskapsakademien grundades att det karolinska enväldets oarter antingen var borta eller på väg att övervinnas. Frihetstiden buntades sålunda samman med den gustavianska eran och positionerades tillsammans med den mot det karolinska tidevarvet. Hattpartiet bedömdes välvilligt. Den "Flock af ädelsinta och driftiga Medborgare, som verkade besluten på den näst före detta 40-år[ig]a tidehvarf gående Riksdagen [1738-39]" hade förändrat folkets lynne till det bättre, medan deras patriotism inspirerat till akademiens instiftande och till en berömvärd strävan för såväl nyttiga konster och vetenskaper som landets väl. Mycket hade förkovrats och hushållningen expanderat: näringarna uppmuntrades, jordbruket bedrevs förnuftigt och planmässigt, bergshanteringen konsoliderades och tillväxte, handeln och penningrörelsen tog fart, handslöjder idkades nitiskt, inhemska råmaterial förädlades, svenska kläder producerades, folkbristen motverkades, den fattige men flitige bereddes utväg till förtjänst. Bergius krönte sitt försvar av hattarna 
med tesen att friheten förutom från Sveriges självständiga fortbestånd utgått från rikets sanna förbättring. Han medgav att utvecklingen varit varken snabb eller fullkomlig, vilket inte kunnat förväntas med hänsyn till att egenmäktighet, krig, missämja och annat kommit emellan, "men grunden var i en god stund lagd, och den står i många hufvudsakeliga delar ännu qvar". ${ }^{579}$

En kontrastering av frihetstiden mot det karolinska enväldet till den förra periodens fördel påträffas även hos andra ledamöter. Naturalhistorikern Olof Swartz tog upp den serie av krig och olyckor som under 1700-talets första två årtionden skadat hushållning och vetenskap, liksom de fredligare makthavare som därefter vidtagit nödvändiga åtgärder för att tillfredsställa behoven. Jordbruket, handeln, bergshanteringen och fisket hade fått regeringens fulla uppmärksamhet: "Förordningar utgåfvos, Inrättningar gjordes, Förslager sattes i verket och drefvos med fördel, samt fullkomnades til Statens heder och nytta." De styrande hade bemödat sig om att sprida nyttiga kunskaper och förbättra ekonomin samtidigt som en naturalhistoriens guldålder infallit tack vare Linné. Eric Prosperin uppmärksammade att Kungliga Vetenskaps-Societeten i Uppsala etablerats vid en tidpunkt då Sverige balanserat på fördärvets rand, pinat av krig, svält och pest. Dess ursprungliga ändamål var att erbjuda en distraktion från alla bedrövelser. Vetenskapsakademien hade däremot inrättats när landet haft fred i två decennier, näringarna tillvuxit ovanligt mycket och svenskarna nästan börjat tröttna på sin välfärd och lycka. ${ }^{500}$ Huruvida Bergius, Swartz eller Prosperins värderingar av frihetstiden och det karolinska enväldet hade bäring på den gustavianska autokratin är svårt att avgöra; det kan inte uteslutas att en sådan avsikt förelåg.

När frihetstidens defekter behandlades i anslutning till Gustav III och hans regering var syftet rimligen att kontrastera dem mot varandra för att framhäva och förhärliga konungen. Läkaren Nils Dalberg fastställde att riket räddats från undergången 1772 - ett alltid anmärkningsvärt år som var ett av historiens lyckligaste, om än också ett av de värsta på länge på grund av svåra farsoter. Sjukdomarna härrörde från en utbredd missväxt som förvärrats av att den politiska splittringen omöjliggjort effektiv distribuering av säd till de drabbade områdena. ${ }^{581}$ 
Nils Adam Bielke talade om blinda och yra folk som höll

lagen för träldom, ordning för tvång, sjelfsvåld för rättigheter, och frihet för en myndighet at obehindradt få göra dårskaper: hvilkas motbjudande vilja, värdig följeslagare af et trångt begrep [förstånd], sätter sig emot de hälsosammaste författningar, och klandrar alt, hvad ej i deras hjerna uprunnit. Oförnöjde med alt, kasta sig utan eftertanka, utur den ena ytterligheten i den andra: som, jäsande af högmod, söfde [sövda] i lättja, dränkte i yppighet, tryckte af fattigdom, fale [till salu] för den mästbjudande, med allmänt bästa i munnen, hysa nedriga och enskilda [egennyttiga] afsickter i hjertat: Regerings-sjuke, oenige sins imellan, afvundsjuke på hvarannan [varandra], sökande hälst sin upkomst på medborgares förtryck och det allmännas bekostnad: hos hvilka änteligen [slutligen] all dygd, ära och kärlek för Fäderneslandet äro utkolnade [utslocknade]. Et sådant Folkslag är det olyckligaste af alla. Det står ej at hjelpa, utan tilskapar sin egen ofärd, och rusar til sin oundvikliga undergång.

Bielke ställde detta slags folk mot en sort som styrdes av en kärleksfull furste, vilken månade om de underlydandes frihet, säkerhet och äganderätt, hade "Fäderneslandet" till valspråk samt titulerade sig "den Förste Medborgaren ibland et rättskaffens fritt folk". Om undersåtarna fyllda av flit, laglydnad, trohet, enighet, ära och dygd sökte leva upp till sin monark och infriade hans förväntningar var deras framtidsutsikter strålande. ${ }^{582}$ Gustav III:s valspråk var just "Fäderneslandet" och konungen hade redan 1771 utmålat sig som den förste medborgaren bland ett fritt folk; han kom under hela sin regering att knyta termen "medborgare" till kungavärdigheten. ${ }^{53}$ Bielkes tydliga anspelning på Gustav gör det sannolikt att hans resonemang om yra och blinda folk handlade om frihetstiden, som på vedertaget manér förbands med egenmäktighet, söndring och falsk frihet.

Sandels framförde att näringarna under frihetstiden hotats av egennytta och antipati, vilka snart skulle ha triumferat om det inte varit för den lyckliga statsvälvningen. Han använde uppenbarligen 1500talet som en spegel för samtiden när han skildrade hur Försynen sänt Gustav Vasa för att rädda Sverige från värsta elände och vanmakt. Fast konungen omgivits av oroligheter, uppror och stämplingar motiverade 
av" in- och utrikes bitterhet, afvund och egennytta" hade han skyndsamt lyft upp ett i generationer skövlat och förtryckt fädernesland. Gustav Vasas älskade namn frammanade alltid hågkomsten av hans stordåd, som skickat egennytta, oordning, våld, tyranni, vidskepelse och andliga villfarelser på dörren. Hans tidevarv var "det första GUSTAVIANSKA" och oförglömligt som den svenska hushållningens första lyckosamma period. Utsagorna bör i hög grad ha varit ämnade att föra tankarna till den tredje Gustaven, som ju gestaltades som en gudagiven riksbefriare och nyttofurste analog med Gustav Vasa. ${ }^{584}$

Endräkt hade redan under frihetstiden varit ett ideal i Vetenskapsakademien, med avseende på både samhället och den egna organisationen. Presidietal framförde ståndpunkterna att oenighet och partier varslade om ett lands förstörelse och att enighet skulle utmärka såväl akademiens "samhälle" som samhället i stort så att Sverige kunde upphjälpas. ${ }^{55}$ Även gustavianska tal kommenterade Vetenskapsakademiens inre sammanhållning. Det konstaterades att akademien alltid utmärkts av samförstånd, att dess ädlaste egenskap var sämja och gemensam nit samt att ledamöterna såg vänskap, förtroende och hövlighet som sin kollektiva själ varför inga avsteg från endräkten tolererades. ${ }^{586}$

Om frihetstiden hade erbjudit falsk frihet tillhandahöll Gustav III:s regering den äkta varan. Carl Fredrik Scheffer kungjorde att den sanna friheten var hälsosam och oundgänglig för det allmänna bästa. Den utgjorde raka motsatsen till de försyndelser som tidigare haft namn av frihet och tillmätts hela den tyngd och alla de företräden som endast hörde "den egenteliga äkta Friheten" till. Den sanna friheten innebar att de lastbara inte kunde förverkliga sina begär och att lagen var ensamt rådande, vilket var det enda som kunde trygga samtliga invånares säkerhet - "hvad man i alla tider med den Politiska Friheten förstått". Frihetstidens lagar hade lyckligt eliminerats genom konungens nya och helt unika grundlag, som till skillnad från "de mäste fria Staters" motsvarigheter inte var ett planlöst lappverk utan skapad vid ett enda tillfälle. Gustavs konstitution bar löfte om varaktighet eftersom den var vis och välavvägd - präglad av en fast grund, tydlighet, frånvaro av förtryck samt nogsam balans mellan folkets frihet och regentens myndighet. Författningen säkerställde den äkta friheten, givet att monarken hade 
befogenhet att härska, freda och försvara men inte att förtrycka, störa eller attackera. Undersåtarna åtnjöt säkerhet och frihet i allt som rörde det enskilda, som hade bättre skydd i Sverige än någon annanstans. ${ }^{587}$

Scheffer röjde en långtgående optimism inför den gustavianska eran, under vilken konungens sunda politik skulle få enastående konsekvenser för riket. Grundlagen skulle föra med sig maximal lycka, den naturliga ordningen respekteras, privategendomen vårdas med andakt, näringarna beskyddas och ges stor frihet, vetenskaper och konster nå sin högsta potens. Den förståndiga lagstiftningen och "oinskränkta Friheten" skulle åstadkomma flit och förbättrade seder samt visa att industrins enda hinder bestod i tvång och felaktiga eller alltför många lagar. ${ }^{588}$

Friheten var ett återkommande gustavianskt ledmotiv. Sandels erinrade om att riket ibland befunnit sig i en olycklig situation - frihetstiden - och om "en lyckelig utgång" - statsvälvningen - som blev desto lyckligare av att inbyggarna efter denna med större förtröstan än under den så kallade frihetstiden kunde glädja sig åt "en laglig, en oskattbar frihet och säkerhet”. Lilliestråle förkunnade att Gustav III skaffade undan oskick och lät friheten komma till sin rätt. Han citerade Plinius den yngres hyllning av Troja, som nu fick avse den svenske monarken: "Du befaller oss vara frie; vi äro det. Du befaller oss frambära hvad vi tänke: vi frambäre. Han skall derföre altid få, hvad Han öfvertygat oss om, och förmärka, at så ofta vi bruke den frihet Han oss gifvit, lyde vi Honom." Kloka tänkare hade visat att vetenskaperna trivdes i fria länder, vilket betydde att de trivdes allra bäst i Sverige, där äkta frihet var mest stadgad. Carl Peter Thunbergs beskrivning av japanernas frihet hade påtagliga gustavianska övertoner, eftersom den enligt honom inte var av det slag som tenderade att övergå i tygellöshet och självsvåld, utan en lagbunden frihet som omfattade alla. Han riktade samtidigt kritik mot Sverige, vars jordbruk sades vara mer ofritt än det japanska. ${ }^{589}$

Friheten diskuterades utförligt av Rosenstein den yngre, som frångick de vedertagna, regimtrogna ståndpunkterna i den gustavianska Vetenskapsakademien. Han ansåg att lycksalighet förutsatte rättigheterna personlig frihet och säkerhet - "fritt bruk af våra förmögenheter, säkerhet under detta bruk" - och att tvång och träldom utgjorde det värsta onda. Dessa rättigheter gick att kombinera med alla lagbundna 
regeringssätt, monarkiska eller republikanska, och kunde inte med rättvisa undanhållas människorna. Resonemanget utmynnade i två radikala ställningstaganden, förespråkandet av tankefrihet och tesen att upplysning var en rättighet: "Skaparen har ej skänkt oss förgäfves Förståndet, icke förgäfves gjort Tankan til det friaste i naturen, icke förgäfves satt henne [den] utom människors våld. Huru har då någon dödlig trodt sig äga rättighet, at förhindra Förståndets bruk, trodt sig äga förmåga at fjättra tankan?” Svenskarna kände den personliga friheten eftersom de var fria genom lagarna..$^{590}$

Lagstiftningen skulle ur Rosensteins synvinkel ge människor säkerhet och frihet i utövandet av deras färdigheter, men avhålla sig från onödigt tvång och från att motverka det naturliga framåtskridande som bottnade i "den mäst verksamma drift i människo-själen". Ett repressivt system var inte bara fåfängt och orättvist, utan dömt att gå under. Rosenstein hävdade vidare att all lydnad utgick från lagarna, vilka både mäktiga och svaga måste underkasta sig. Han framställde laglydnaden som helt central för samhällsordningen. Denna lydnad skulle dock inte vara blind utan upplyst; den som regerade utifrån lagen blev säkrast hörsammad och de lagar som gemene man trodde på säkrast efterlevda. ${ }^{591}$ Argumentationen anspelade på Gustav III:s "andra revolution", den för Rosenstein misshagliga förenings- och säkerhetsakten 1789 - ett försök att återinföra Gustav II Adolfs regeringsform som gav konungen mer eller mindre absolut makt. Den eliminerade ständernas initativrätt inom lagstiftningen och upphävde rikets råd, medan suveränen tillskansade sig rätten att starta krig och full kontroll över förvaltningen. ${ }^{592}$

Säkerhet var ett annat viktigt tema i de gustavianska presidietalen men förekom liksom enigheten och sämjan redan i frihetstida tal, som skildrade holländarnas säkerhet till liv och egendom i positiva termer och stipulerade att envar hade rätt till sitt liv och sin egendom. ${ }^{593}$ Det sistnämnda var ett framträdande politiskt debattämne under frihetstidens sista år, förmodligen som en reaktion på partiförföljelserna och den åtföljande rättsosäkerheten. ${ }^{594}$

Gustavianska akademimedlemmar deklarerade att konungen inriktade sig på undersåtarnas säkerhet och egendomsrätt. Han uppgavs återupprätta allmän och enskild säkerhet och göra lagen till ett trygghetens 
värn, vars okränkbarhet dygden fordrade. Det segment av mänskligheten som Gud tilldelat honom var i besittning av alla sina rättigheter och fick sålunda optimal uppmuntran. Säkerhet att njuta frukterna av sitt arbete garanterade, vid sidan av den arbetande befolkningens upplysning, landets förbättring, och invånarna kunde glädjas åt en ny tid som den store monarken inlett genom att bemöda sig om såväl friheten som säkerheten. ${ }^{595}$ Ett antal presidietal diskuterade äganderätten, samhällets ömtåligaste band, som gav nytta och skulle bereda alla säkerhet. Det hette att Gustav ömmade för egendomsrätten och att politin tryggade den säkerhet om liv och egendom som han försäkrat sitt folk. ${ }^{596}$ Rosenstein den yngre hade en delvis fientlig inställning till äganderätten, som enligt honom lett till ekonomisk ojämlikhet och därmed till fler bekvämligheter, överflöd, lyx och allt ont människor klagade över. Han förhöll sig likväl negativ till Spartas avskaffande av egendomsrätten, liksom till romarnas fruktlösa och naturvidriga ansats att vända bort intresset från materiella ting. Äganderätten utgjorde ytterst ett villkor för en riktig frihet och inga lagar hade åtlytts mer än de som säkerställde liv och egendom. ${ }^{597}$

Frihet och säkerhet var återkommande värden i Gustav III:s Sverige, där de präglade både hans självbild och propaganda och Vetenskapsakademiens presidietal och politiska ideologi. Inte ens den så kritiskt sinnade Rosenstein låg alltför långt borta från det mentala och retoriska ramverk som monarken nötte in under sin tid vid riksrodret.

Den inverkan på Vetenskapsakademiens politiska ideologi som närheten till de frihetstida regenterna hade var märkbar, men går inte att jämföra med effekterna av närheten till hattpartiet, medan samröret med den gustavianska kungamakten fick lika stora konsekvenser som samröret med hattarna.

Samtliga konungar under undersökningsperioden - Fredrik I, Adolf Fredrik och Gustav III - gestaltades som drivande nyttofurstar, under vilkas styren hushållningen, näringarna, vetenskaperna och landet förbättrades och nådde nya höjder. Alla tre beskrevs också som stora, nådiga, milda, visa, kultiverade, omsorgsfulla, idoga och patriotiska 
regenter älskade av folket. Adolf Fredrik och Gustav III porträtterades i motsats till Fredrik I som landsfäder och föredömen för gemene man. Kronprins- och kungaparet Adolf Fredriks och Lovisa Ulrikas insatser för lärdomen framhölls, vilket torde ha hängt samman med deras relation till Vetenskapsakademien. Analysen bekräftar sammantaget att svenska monarker fortsatte besitta en stark symbolisk makt under frihetstiden, inte minst med hänsyn till hushållningen.

Den begränsade kungamakten var ett ovanligt ämne i presidietalen under Fredrik I:s regering, men blev mer frekvent under 1750-talets första hälft och upptakten till det misslyckade rojalistiska statskuppsförsöket 1756. Förändringen sammanföll med tilltagande friktion mellan kungaparet och hattregimen, och med att interaktionen mellan kungahuset och akademien försvagades för att till sist avstanna. Efter kuppstämplingarnas avslöjande förbigick talen i ett års tid kungligheterna med tystnad, och hänvisningarna till dem var som regel få och opersonliga fram till 1762. Hattpartiets närmande till monarkerna resulterade då $i$ att de under en period kom att framställas på ungefär samma sätt som före 1750-talets slitningar. Under mössornas maktinnehav 1765-69 minskade referenserna till kungligheterna på nytt, låt vara i lägre grad än efter 1756 års händelser, medan närvaron ökade igen efter deras allierade hattarnas återkomst till makten 1769. Skiftena i presidietalens hantering av kungahuset åskådliggör att denna var avhängig monarkernas förhållande till hattarna och understryker att Vetenskapsakademien utgjorde en integrerad del av partiets nätverk och maktapparat. Ledamöterna var likafullt inte sena att anpassa sig och sina tals budskap efter statsvälvningen 1772, när deras och akademiens lojaliteter skyndsamt flyttades över på den nya regimen.

Partistriderna och deras negativa följdverkningar togs upp av flera ledamöter mot frihetstidens slut. Temat fortlevde och förstärktes under den gustavianska tiden, då den tidigare epoken tillskrevs självsvåld, osämja, egennytta, godtycke, korruption, svaghet, tvång, undermålig lagstiftning, falsk frihet och hotande undergång. Det hände dock att frihetstiden attribuerades en övervägande eller delvis gynnsam ekonomisk utveckling, oftast i samband med att den ställdes mot det karolinska 
enväldet och det stora nordiska kriget. Åtminstone för Bengt Bergius och Sandels tycks försvaret av den i hög grad ha varit ett försvar av hattarna.

Gustav III betraktades från första början som "den tredje Gustaven" och parallelliserades framgent med sina berömda namnar, framför allt Gustav Vasa. Han blev vid sitt trontillträde föremål för omfattande smicker, vilket kan förklaras med de stora förhoppningar som knöts till honom i skuggan av de rådande krisstämningarna och med en tidstypisk rojalistisk tendens som anammades av ett flertal hattar. Å andra sidan riktade några av de senfrihetstida ordförandena kritik mot historiska autokratier, som av allt att döma fick fungera som projektionsytor för antirojalistiska attityder. Vetenskapsakademiens förbindelser med regenten blev av naturliga skäl mycket viktigare efter statsvälvningen. Gustav intog en betydligt mer framskjuten plats i presidietalen än sina företrädare, och de egenskaper som tillmätts dem skruvades upp ett snäpp i skildringarna av honom. Han kom också att till skillnad från Fredrik I och Adolf Fredrik omges av en utvecklad religiös retorik, som passade väl med talens ödesmättade skildringar av frihetstiden. Ledamöterna föreställde i likhet med den kungliga propagandan Gustav som en befriare och frälsare från oordning - hans styre var frihetstidens antites, en era av enighet, trygghet och äkta frihet. En avvikande röst var Rosenstein den yngre, som tog till sig det kungliga politiska språket men använde det för att förorda tankefrihet och kritisera förenings- och säkerhetsakten.

Vetenskapsakademiens idéskapande kring regenterna harmonierade liksom idéskapandet kring hattarna med akademiens uppfattningar om samhällsledningen och samhället i stort. Den politiska ideologin förblev sig lik över olika områden. Nästa kapitel behandlar hur organisationen uttryckte sin närhet till makthavarna och eliten samtidigt som dess syn på den egna samhällsrollen granskas. 